\title{
Analysis of the Effectiveness of Monetary Policy Transmission (Evidence in Indonesia and Thailand)
}

\author{
Ali Anis ${ }^{1}$, Hari Setia Putra ${ }^{2}$,Nanda Alfarina ${ }^{3}$, Zul Azhar ${ }^{4}$ \\ 1Universitas Negeri Padang, Padang, Indonesia, $\square$ alianis@fe.unp.ac.id \\ ${ }^{2}$ Universitas Negeri Padang, Padang, Indonesia, $\square$ hari.putra@fe.unp.ac.id \\ ${ }^{3}$ Universitas Negeri Padang, Padang, Indonesia, $\square$ alfarinananda@gmail.com \\ ${ }^{4}$ Universitas Negeri Padang, Padang, Indonesia, $\bowtie$ zul.azhar.unp@gmail.com
}

\begin{abstract}
This study aims to analyze the effectiveness of monetary policy transmission in Indonesia and Thailand through the interest rate channel for the period of 2006Q1-2018Q4. Data analysis method uses VAR / VECM. Before the data is processed, stationary test (unit of root test), optimum lag determination, Johansen co-integration test, Granger causality test, impulse response function and decomposition variance will be conducted. Response Function analysis results show the response of other variables to changes in one variable in the short, medium and long term, and it is known that the stability of the responses of all variables is formed in the 10 quarter or long-term period.
\end{abstract}

Keywords: Interest rate, Monetary Policy, Inflation

\section{Introduction}

The International Monetary Fund (IMF) defines monetary policy as the main tool in controlling and achieving price stability and for helping maintain economic fluctuations. Monetary policy is the most active tool used for macroeconomic stabilization in countries with independent currencies (Arwatchanakarna, 2017). To do this well, they need to know how changes in policy instruments affect the economy (Cesa-Bianchi, Thwaites and Vicondoa, 2016). The strategic framework of monetary policy adopted by the central bank is largely influenced by the confidence of the central bank concerned in a particular process regarding how monetary policy influences economic growth and inflation. The said process is known as the monetary policy transmission mechanism.

The transmission mechanism of monetary policy refers to how changes in short-term interest rate policies affect various economic variables such as investment, output, and employment opportunities (Jain-Chandra and Unsal, 2014), simply is the influence of monetary policy on the financial sector and the real sector (Rusiadi; Novalina and Sembiring, 2017). The ultimate goal of monetary policy is price level stability or inflation. This mechanism can occur through money, interest rates, credit, exchange rates, and asset price lines. But some economists only focus on one path, is Mishkin (1995) which makes the interest rate channel the standard of monetary policy transmission (Arwatchanakarna, 2017). Of the various channels, price stability remains the main target. Price stability is the ultimate target of monetary policy in various countries.

The monetary policy transmission mechanism for the interest rate path begins with changes in the central bank's interest rates which then affect the short-term interbank money market interest rates. Then it affects deposits and credit rates in commercial banks and the rate of return on government and private bonds. Because of economic rigidity, the central bank not only affects nominal interest rates, but also affects real interest rates. Real interest rates influence the decision to invest and consume or saving (Rusiadi; Novalina and Sembiring, 2017). In general, the transmission of monetary policy through the interest rate channel directly affects two sides, first increasing the cost of capital thereby reducing interest in investing. Reduced investment decreases aggregate supply. The second side is an increase in interest rates increasing interest rate income for savers, which increases the purchasing power (income effect) but 
on the other hand reduces substitution effects. Net effects both determine the amount of consumption, which ultimately affects aggregate demand (Herlina, 2018).

Research conducted by (Jain-Chandra and Unsal, 2014), shows that the transmission of monetary policy on interest rates in the Asian market is largely influenced by global factors, especially with integrated financial markets and free capital movements. However, in this study it was also found that transmission of monetary policy channel interest rates remained strong, especially short-term interest rates.

The effectiveness of the transmission of monetary policy is measured from two indicators, first, namely how much speed or deadline (time lag) and the second is how much the variables in responding to the existence of monetary policy instrument shocks. The main questions that will be answered in this paper are:

1. How is the mechanism for transmitting monetary policy on interest rates in Indonesia for the 2006Q1-2018Q4 period?

2. How is the mechanism for transmitting monetary policy on interest rates in Thailand for the 2006Q1-2018Q4 period?

Based on this, the purpose of this study was to identify the effectiveness of the monetary policy transmission mechanism for interest rate lines in terms of the effect of cost of capital and income substitution in the Asian Market country with case studies in Indonesia and Thailand.

The research was carried out by (Herlina, 2018), namely with the title "Identification of Monetary Policy Transmission Mechanisms for Monetary and Channel Channels in Indonesia". In this study the authors compared the two pathways using the cost of capital approach and the consumption effect approach on the interest rate pathway while the money line refers to the Quantity Theory of Money theory. This study provides the conclusion that the monetary policy mechanism in the interest rate channel with the approach of the cost of capital is more effective in transmitting monetary policy to the real economy. While the transmission of monetary policy on the path of quantity of money and channel interest rates through consumption effects is not effective in transmitting monetary policy to the real economy. This means that the interest rate pathway through the effect of capital costs is better able to explain the transmission of monetary policy in influencing the real economy, both economic growth and the ultimate goal of monetary policy itself, namely inflation.

Meanwhile the research conducted by (Chen, Chow and Tillmann, 2016) with the title "The Effectiveness of Monetary Policy in China: Evidence from a Qual VAR" shows that the transmission mechanism of credit lending (bank lending) is less effective in China. The impact of monetary policy on stock prices, credit growth, and housing prices shows that monetary policy is not the right instrument in achieving financial system stability. Instead, researchers suggest to conduct further research on the impact of changes in short-term interest rates as the main instrument of monetary policy.

\section{Methods}

The data used in this paper are data on Central Bank Policy Interest Rates (I), Investment Credit Interest Rates (Rkre), Deposit Interest Rates (RDEP), Inflation (INF), GDP Log (LGDP), Direct Foreign Investment (INV), Private Sector Direct Consumption Log (LCONS) which is time series data for the time period of 2006Q1-2018Q4. Data was obtained from Bank Indonesia, Central Bank of Thailand, the Indonesian Central Bureau of Statistics, and Statistics Thailand Data. To see the relationship and how macroeconomic variables affect inflation the tests carried out include stationarity test using Augmented Dickey Fuller (ADF), then optimal lag length test, co-integration using Johansen co-integration test, and analysis performed with Vector Error Correction Model (VECM), Vector Auto Regression (VAR), and Impulse Response Analysis. The VAR / VECM equation model in this study is as follows: 


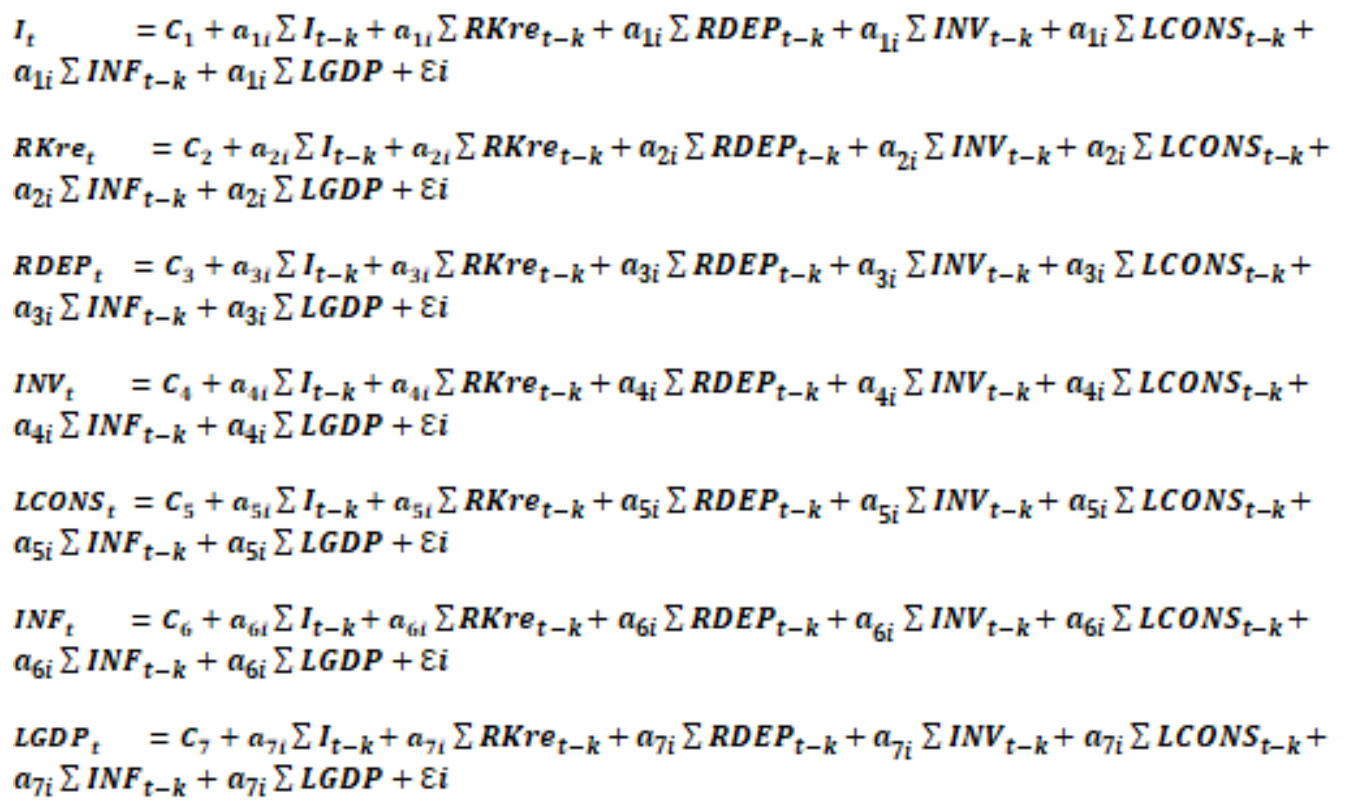

Where:

$\begin{array}{ll}\alpha & : \text { Coefficient } \\ \text { C } & : \text { Constants } \\ \text { I } & : \text { Policy Rates } \\ \text { RKre } & : \text { Credit Interest Rate } \\ \text { RDEP } & : \text { Deposit Interest Rate } \\ \text { INV } & : \text { Foreign Direct Investment } \\ \text { LCONS } & : \text { Log Private Consumption } \\ \text { INF } & : \text { Inflation } \\ \text { LGDP } & : \text { Log GDP Growth } \\ \varepsilon_{\mathrm{i}} & : \text { error term }\end{array}$

\section{Results and Discussion}

This research began with several tests conducted previously, namely stationarity test, optimum lag length test, VAR model stability test, Granger causality test, and co integration test. In this study found co integration in both Thailand and Indonesia, so that the right model to use is the VECM model. Besides that, IRF and VD tests were also carried out.

The decomposition results for short-term (1 quarter) inflation in Thailand indicate that inflation is explained by inflation itself at 100 percent, while in Indonesia it is $83.17 \%$. Variables other than inflation that have the greatest influence on inflation in Thailand are Rkre, where in the medium term (5 quarter) Rkre contributes to influencing inflation in Thailand by $18.18 \%$. While in Indonesia, in the short term, medium term and long term (10 quarter) is a variable other than inflation which gives the biggest influence to inflation, namely the policy interest rate (I) which is equal to $16.82 \%$. In Indonesia, the policy interest rate, namely the BI 7 Day Repo Rate is set at the monthly Board of Governors Meeting. The Bank Indonesia policy rate is the main instrument in controlling inflation in Indonesia.

\section{Stationarity Test}

Based on the ADF Test it can be seen that several stationary variables at the level of the level are RDEP, ILSS, and LKLSS. While the rest, namely the BI Rate, RKI, LRGDP and Inflation are not stationary 
at the level but rather stationary at the level of the first difference. From the results of the test it is known that all variables in this study are stationary at the first degree of integration.

Table 1 ADF Test Results

\begin{tabular}{|c|c|c|c|c|c|}
\hline \multirow[b]{2}{*}{ Variable } & \multirow[b]{2}{*}{$\begin{array}{c}\text { Unit Root } \\
\text { Test }\end{array}$} & \multicolumn{2}{|c|}{ Indonesia } & \multicolumn{2}{|c|}{ Thailand } \\
\hline & & $\begin{array}{c}\text { ADF Test } \\
\text { Statistic }\end{array}$ & $\begin{array}{c}\text { Critical } \\
\text { Values } \\
5 \%\end{array}$ & $\begin{array}{c}\text { ADF Test } \\
\text { Statistic }\end{array}$ & $\begin{array}{c}\text { Critical } \\
\text { Values } \\
5 \%\end{array}$ \\
\hline \multirow{2}{*}{ I } & Level & -3.738840 & -2.921175 & -1.674992 & -2.919952 \\
\hline & $1^{\text {st }}$ Difference & -4.083792 & -2.921175 & -6.700516 & -2.921175 \\
\hline \multirow{2}{*}{ Rkre } & Level & -2.801472 & -2.925169 & -2.403108 & -2.921175 \\
\hline & $1^{\text {st }}$ Difference & -4.416178 & -2.925169 & -5.164720 & -2.925169 \\
\hline \multirow{2}{*}{ RDEP } & Level & -3.938871 & -2.921175 & -3.133083 & 2.921175 \\
\hline & $1^{\text {st }}$ Difference & -4.196210 & -2.922449 & -4.762726 & -2.922449 \\
\hline \multirow{2}{*}{ INV } & Level & -3.994780 & -2.919952 & -7.042030 & -2.919952 \\
\hline & $1^{\text {st }}$ Difference & -7.233018 & -2.923780 & -7.096188 & -2.923780 \\
\hline \multirow{2}{*}{ LCONS } & Level & -0.244302 & -2.925169 & -1.252873 & -2.926622 \\
\hline & $1^{\text {st }}$ Difference & -4.034330 & -2.925169 & -4.077673 & -2.926692 \\
\hline \multirow{2}{*}{ INF } & Level & -2.801472 & -2.925169 & -4.812543 & -2.922449 \\
\hline & $1^{\text {st }}$ Difference & -4.416178 & -2.925169 & -2.568703 & -2.935001 \\
\hline \multirow{2}{*}{ LGDP } & Level & -2.188291 & -2.919952 & -4.615393 & -2.923780 \\
\hline & $1^{\text {st }}$ Difference & -6.292519 & -2.921175 & -5.093780 & -2.925169 \\
\hline
\end{tabular}

Source: Author's processed results

\section{Lag Length Test Results}

The choice of the optimal lag in this study is based on the SC (Schwarz Information Criterion). Based on the optimum lag test, lag order selection is the optimal lag length with the smallest SC value in lag 5. Where the results of the lag length test in Indonesia show the SC value of 12.79 and in Thailand at 37.16.

\section{Stability Test of the VAR Model}

To test the stability of the VAR model formed, the VAR Stability condition is performed in the form of roots of characteristic polynomial. (Gujarati, 2003) a VAR model is said to be stable if all its roots have modulus smaller than one.

Based on the results of the VAR model stability test that has been done, the VAR model that was formed has been stable in Thailand and Indonesia because all its roots have modulus smaller than one. So the VAR estimation that will be used for RF and VD analysis is stable and valid.

\section{Granger Causality Test Results}

Causality tests are conducted to determine whether an endogenous variable can be treated as an exogenous variable. This starts from ignorance of influence between variables. Causality tests can be done with various methods including the Granger's Causality and Error Correction Model Causality methods.

In this study, the Granger's Causality method was used. The Granger's Causality is used to test the causality relationship between variables. Predictive power from the previous information can show the existence of a causality relationship between variables for a long time. In testing Granger Causality, if the probability value is less than $10 \%$ it means that the variable has a causality relationship.

Based on the results of Granger's causality test, no causality relationship was found in each variable both in Indonesia and in Thailand. 


\section{Co-integration Test Results}

This study uses the Johansen test, co-integration determination is seen from the value of the trace statistic and max Eigen statistic after being preceded by finding the lag length that will be known. If the value of the trance statistic is smaller than the critical value it can be concluded that the two variables are not mutually integrated (Winarno, 2006: 11.7).

Based on the results of the econometric analysis above, it can be seen that among the seven variables there are five co-integrations at a significant level of $5 \%$ in Thailand and one of co-integration in Indonesia. Based on the results of these tests, the most appropriate model used in this study is the Vector Error Correction Model (VECM).

Table 2 Co-integration Test Results

\begin{tabular}{|c|c|c|c|c|c|c|}
\hline \multirow{2}{*}{$\begin{array}{l}\text { Hypothesized } \\
\text { No. Of CE(s) }\end{array}$} & \multicolumn{3}{|c|}{ Thailand } & \multicolumn{3}{|c|}{ Indonesia } \\
\hline & $\begin{array}{c}\text { Trace } \\
\text { Statistic }\end{array}$ & $\begin{array}{c}\text { Critical } \\
\text { Value (5\%) }\end{array}$ & Prob.** & $\begin{array}{c}\text { Trace } \\
\text { Statistic }\end{array}$ & $\begin{array}{c}\text { Critical } \\
\text { Value (5\%) }\end{array}$ & Prob.** \\
\hline None ${ }^{*}$ & 398.8805 & 125.6154 & 0.0000 & 149.2019 & 125.6154 & 0.0008 \\
\hline At most $1^{*}$ & 218.2221 & 95.75366 & 0.0000 & 95.61055 & 95.75366 & 0.0511 \\
\hline At most $2^{*}$ & 139.6079 & 69.81889 & 0.0000 & 53.49402 & 69.81889 & 0.4835 \\
\hline At most $3^{*}$ & 85.64030 & 47.85613 & 0.0000 & 34.30762 & 47.85613 & 0.4851 \\
\hline At most $4^{*}$ & 40.01512 & 29.79707 & 0.0024 & 16.25086 & 29.79707 & 0.6945 \\
\hline At most $5 *$ & 12.75262 & 15.49471 & 0.1242 & 6.044673 & 15.49471 & 0.6903 \\
\hline At most $6^{*}$ & 0.502961 & 3.841466 & 0.4782 & 0.050625 & 3.841466 & 0.8220 \\
\hline
\end{tabular}

Source: Author's processed results

\section{Vector Error Correction Model}

The co integration test that has been done before shows that there is a co integration relationship between variables, both in Thailand and in Indonesia, the right analysis model to use is VECM (Vector Error Correction Model). Based on the optimum lag test, the optimum lag in the VECM analysis is lag 5, so that in this test the lag used is lag 4 (5-1). The results of the VECM analysis are then compared with the $\mathrm{t}$-table with an alpha level of $5 \%$, which is 1,745 .

Table 3 Relationship of each Significant Variable in Thailand

\begin{tabular}{lllll}
\hline $\begin{array}{c}\text { Var. } \\
\text { Independent }\end{array}$ & $\begin{array}{c}\text { Var. } \\
\text { Dependent }\end{array}$ & Coefficient & t-Statistic & Result \\
\hline $\mathrm{D}(\mathrm{INF}(-4))$ & $\mathrm{D}($ LCONS $)$ & 0.017599 & {$[$ 1.99152] } & Significant \\
\hline $\mathrm{D}(\mathrm{INF}(-4))$ & $\mathrm{D}($ LGDP_) & 0.443746 & {$[$ 2.45344] } & Significant \\
\hline $\mathrm{D}(\mathrm{INF}(-4))$ & $\mathrm{D}($ RDEP $)$ & -0.036982 & {$[-2.05990]$} & Significant \\
\hline $\mathrm{D}(\mathrm{INF}(-4))$ & $\mathrm{D}($ RKre $)$ & -0.223232 & {$[-1.83238]$} & Significant \\
\hline $\mathrm{D}(\mathrm{INF}(-4))$ & $\mathrm{D}(\mathrm{I})$ & -94.58830 & {$[-1.98941]$} & Significant \\
\hline $\mathrm{D}(\mathrm{LCONS}(-4))$ & $\mathrm{D}($ LCONS & 0.685984 & {$[\mathbf{1 . 9 5 6 7 9}]$} & Significant \\
\hline $\mathrm{D}(\mathrm{LCONS}(-4))$ & $\mathrm{D}($ RDEP $)$ & -2.889378 & {$[-4.05686]$} & Significant \\
\hline $\mathrm{D}($ LGDP_(-4)) & $\mathrm{D}($ LGDP_) & -0.562855 & {$[-2.93109]$} & Significant \\
\hline $\mathrm{D}($ RKre $(-4))$ & $\mathrm{D}($ RKre $)$ & -0.945028 & {$[-3.08483]$} & Significant \\
\hline $\mathrm{D}($ RKre $(-4))$ & $\mathrm{D}(\mathrm{I})$ & -765.7429 & {$[-6.40467]$} & Significant \\
\hline $\mathrm{D}(\mathrm{I}(-4))$ & $\mathrm{D}(\mathrm{I}(-4))$ & 1.115399 & {$[$ 4.92410] } & Significant \\
\hline
\end{tabular}

Source: Author's processed results 
Based on the results of the VECM test in table 3 it is known that several variables affect other variables. By comparing the $t$-statistic value with t-table at $5 \%$ alpha level which is 1,745 and in the fourth lag, the INF variable has a positive significant effect on the consumption variable and LGDP, while on RDEP (Deposit Interest Rate) and Rkre (Investment Credit Interest Rate) inflation has a significant negative relationship. While the consumption variable shows a significant negative effect on RDEP, that is, the t-statistic value is greater than the $t$-table value $(-4.0568>-1.745)$. The next variable is the credit interest rate that affects the policy interest rate $(\mathrm{I})$, which is a negative significant influence with a $\mathrm{t}$ statistic value greater than the $t$-table value $(-6.4046>-1.745)$.

Table 4 Relationship of Each Significant Variable in Indonesia

\begin{tabular}{|c|c|c|c|c|}
\hline $\begin{array}{c}\text { Var. } \\
\text { Independent }\end{array}$ & $\begin{array}{c}\text { Var. } \\
\text { Dependent }\end{array}$ & Coefficient & $\mathrm{t}$-Statistic & Result \\
\hline $\mathrm{D}(\mathrm{INF}(-4))$ & $\mathrm{D}(\mathrm{INF})$ & 0.834158 & [ 2.27842] & Significant \\
\hline $\mathrm{D}(\mathrm{INF}(-4))$ & D(LCONS & -0.001336 & {$[-1.80692]$} & Significant \\
\hline $\mathrm{D}(\mathrm{INF}(-4))$ & $\mathrm{D}($ LGDP) & 0.029241 & [ 1.95954] & Significant \\
\hline $\mathrm{D}(\mathrm{INF}(-4))$ & D(LRKRE) & 0.196652 & [ 2.71021] & Significant \\
\hline $\mathrm{D}(\operatorname{LGDP}(-4))$ & $\mathrm{D}(\mathrm{INF})$ & 10.73443 & [ 2.30851] & Significant \\
\hline D(LGDP(-4)) & D(LRKRE) & 1.840187 & [ 1.99679] & Significant \\
\hline D(LRKRE(-4)) & $\mathrm{D}(\mathrm{INF})$ & -6.440116 & {$[-2.84116]$} & Significant \\
\hline D(LRKRE(-4)) & $\mathrm{D}$ (RDEP) & -1.098043 & {$[-2.01606]$} & Significant \\
\hline D(LRKRE(-4)) & D(LRKRE) & -1.283634 & [-2.85733] & Significant \\
\hline
\end{tabular}

Source: Author's processed results

Unlike in Thailand, in Indonesia with a t-statistic value compared to t-table values at alpha 5\% and a four lag, it was found that the INF variable has a negative significant effect on the consumption variable, where the $t$-statistic value is greater than the value $t$-table $(-1.80692>1,745)$. While for LGDP and Rkre variables, INF has a significant positive effect. Vice versa, the LGDP variable a also has a significantly positive effect on INF. LGDP affects Rkre significantly positively with a $\mathrm{t}$-statistic value greater than $\mathrm{t}$ table $(1.99679>1,745)$.

While based on table 4 it can be seen that in Indonesia Rkre has a significantly negative effect on the variables INF, RDEP, and Rkre itself. With the value of $t$-statistic greater than the value of $t$-table which is -2.84116 for the INF variable, -2.01606 for the Rdep variable, and -2.85733 for the Rkre variable, where each of these values is greater than -1.745 .

\section{Impulse Response Function Analysis (IRF)}

The IRF test results indicate the speed or time needed for a variable to respond to changes in other variables. The estimation of the impulse response function is carried out to examine the shock variable response to other variables. Estimates using the assumptions of each innovation variable do not correlate with each other so that the search for the effect of a surprise can be direct.

Table 5 Monetary Variables Affecting Thailand Inflation

\begin{tabular}{cccc}
\hline Period & Short-term & Medium-term (5) & Long-term (10) \\
\hline Own Shock & $92.86 \%$ & $13.48 \%$ & $11.54 \%$ \\
\hline \multirow{2}{*}{ Biggest (1) } & INF & INF & CONS \\
& $92.86 \%$ & $13.48 \%$ & $13.03 \%$ \\
\hline \multirow{2}{*}{ Biggest (2) } & - & RDEP & INF \\
& & $10.65 \%$ & $11.54 \%$ \\
\hline
\end{tabular}

Source: Author's processed results 
Based on Table 5. It is known that the inflation rate in Thailand both in the short, medium and long term is influenced by inflation itself and the amount of household consumption. In addition, the variable that can be used as a recommendation in controlling inflation in the short, medium and long term is RDEP, namely the deposit interest rate.

Table 6 Monetary Variables Affecting Indonesian Inflation

\begin{tabular}{cccc}
\hline Period & Short-term & Medium-term (5) & Long-term (10) \\
\hline \multirow{2}{*}{ Own Shock } & INF & INF & INF \\
& $123.02 \%$ & $39.82 \%$ & $103.98 \%$ \\
\hline \multirow{2}{*}{ Biggest (1) } & INF & LGDP & INF \\
& $123.02 \%$ & $-74.15 \%$ & $103.98 \%$ \\
\hline \multirow{2}{*}{ Biggest (2) } & I & I & I \\
& $55.33 \%$ & $50.81 \%$ & $47.46 \%$ \\
\hline
\end{tabular}

Source: Author's processed results

Table 6. The above shows that the inflation rate in Indonesia both in the short, medium and long term is influenced by inflation itself and economic growth in Indonesia. In addition, the variable that also influences inflation movements is I, which is the interest rate of Bank Indonesia policy. Bank Indonesia interest rates, which are the main instruments for controlling inflation, can influence inflation in the short, medium and long term.

\section{Analysis of Variance Decomposition (VD)}

Variance decomposition aims to measure the magnitude of the contribution or composition of the influence of each independent variable on the dependent variable and the role of itself.

Table 7 Variation Decomposition of Inflation in Thailand

\begin{tabular}{ccccccccc}
\hline Period & S.E. & INF & INV & LCONS & LGDP & RDEP & RKRE & I \\
\hline 1 & 0.928669 & 100.0000 & 0.000000 & 0.000000 & 0.000000 & 0.000000 & 0.000000 & 0.000000 \\
\hline 5 & 1.411704 & 50.02420 & 1.184951 & 23.67629 & 1.476103 & 4.835471 & 18.18723 & 0.615755 \\
\hline 10 & 1.570242 & 45.75371 & 2.254186 & 22.14801 & 4.523025 & 8.730959 & 15.98288 & 0.607236 \\
\hline
\end{tabular}

Source: Author's processed results

In the short term (quarter 1), the result of the variance decomposition which is explained by inflation itself is $100 \%$. In the medium term (5 quarter) inflation is still the variable that gives the most influence, which is equal to $50.02 \%$, while other variables that affect inflation are $23.67 \%$ and investment credit interest rates are $18.18 \%$. While in the long run inflation contributes to inflation of $45.75 \%$ and consumption of $22.14 \%$. This shows that interest rates do not have a significant contribution in influencing inflation in Thailand. In the medium term, the central bank's policy interest rate only contributes $0.61 \%$, while in the long term it is $0.60 \%$, the loan interest rate in the medium term contributes $18.18 \%$ while in the long run it is $15.98 \%$. This finding shows that inflation variability is more dominated by own shock and private sector consumption (LCons). 
Table 8 Variance Decomposition Inflation Indonesia

\begin{tabular}{ccccccccc}
\hline Period & S.E. & I & INF & INV & LCONS & LGDP & LRKRE & RDEP \\
\hline 1 & 1.348997 & 16.82459 & 83.17541 & 0.000000 & 0.000000 & 0.000000 & 0.000000 & 0.000000 \\
\hline 5 & 3.585921 & 35.23084 & 42.12303 & 1.005637 & 1.780865 & 9.271127 & 9.179525 & 1.408973 \\
\hline 10 & 4.313715 & 28.53770 & 46.35759 & 0.726687 & 2.207890 & 9.495835 & 8.495459 & 4.178844 \\
\hline
\end{tabular}

Source: Author's processed results

Based on the table it can be seen that in the short term, inflation is influenced by inflation itself at $83.17 \%$. In the long run inflation affects $42.12 \%$ while the policy rate of the central bank contributes to influencing inflation by $35.23 \%$. Furthermore, in the long run, inflation is influenced by inflation of $46.35 \%$ while the central bank's policy interest rate is $28.53 \%$. In contrast to Thailand, inflation in Indonesia is closely related to policy interest rates, meaning that central bank interest rates contribute significantly to influencing inflation. This finding shows that inflation variability is more dominated by own shock and central bank policy interest rates (I).

\section{Conclusions}

In Thailand in the short term (quarter 1), the result of the variance decomposition which is explained by inflation itself is $100 \%$. In the medium term (5 quarter) inflation is still the variable that gives the most influence, which is equal to $50.02 \%$, while other variables that affect inflation are $23.67 \%$ and investment credit interest rates are $18.18 \%$. This finding shows that inflation variability is more dominated by own shock and private sector consumption (LCons). In contrast to Thailand, inflation in Indonesia is closely related to policy interest rates, meaning that central bank interest rates contribute significantly to influencing inflation. This finding shows that inflation variability is more dominated by own shock and central bank policy interest rates (I).

\section{References}

Arwatchanakarna, P. (2017) 'Structural Vector Autoregressive Analysis of Monetary Policy in Thailand', Sociology Study, 7(3), pp. 133-145. doi: 10.17265/2159.

Cesa-Bianchi, A., Thwaites, G. and Vicondoa, A. (2016) 'Monetary Policy Transmission in an Open Economy: New Data and Evidence from the United Kingdom', Ssrn, pp. 1-43. doi: $10.2139 / \mathrm{ssrn} .2835383$.

Herlina, D. (2018) ‘Identifikasi mekanisme transmisi kebijakan moneter saluran uang dan saluran suku bunga di indonesia', 8(2), pp. 139-158.

Jain-Chandra, S. and Unsal, D. F. (2014) 'The effectiveness of monetary policy transmission under capital inflows: Evidence from Asia', Borsa Istanbul Review. Elsevier Ltd, 14(2), pp. 96-103. doi: 10.1016/j.bir.2014.03.002.

Kubo, A. (2017) 'The macroeconomic impact of foreign exchange intervention: An empirical study of Thailand', International Review of Economics and Finance. Elsevier, 49(October 2016), pp. 243-254. doi: 10.1016/j.iref.2017.02.001.

Mahathanaseth, I. and Tauer, L. W. (2019) 'Monetary policy transmission through the bank lending channel in Thailand', Journal of Asian Economics. Elsevier Inc., 60, pp. 14-32. doi: 10.1016/j.asieco.2018.10.004.

Nguyen, C. and Xuun Vinh, V. (2018) 'Monetary Policy Transmission in Vietnam: A VAR Approach', SSRN Electronic Journal, (April 2016). doi: 10.2139/ssrn.2482259.

Rusiadi; Novalina, A. and Sembiring, R. (2017) 'Efektifitas Mekanisme Transmisi Kebijakan Moneter Melalui Jalur Suku Bunga Terhadap Stabilitas Ekonomi Indonesia', JEpa, 2(2), pp. 1-10.

Sethapramote, P. L. and Y. (2016) 'Central Bank Communication and Monetary Policy Effectiveness: 
Evidence from Thailand', (20).

Sriyono, S. (2016) 'Strategi Kebijakan Moneter Di Indonesia', JKMP (Jurnal Kebijakan dan Manajemen Publik), 1(2), p. 111. doi: 10.21070/jkmp.v1i2.415.

Suseno and Solikin (2002) UANG: Pengertian, Penciptaan, dan Peranannya dalam Perekonomian. doi: 10.1038/cddis.2011.1.

Tai, P. N., Sek, S. K. and Har, W. M. (2012) 'Interest Rate Pass-Through and Monetary Transmission in Asia', International Journal of Economics and Finance, 4(2), pp. 163-174. doi: 10.5539/ijef.v4n2p163.

Thi, N. and Vinh, T. (2015) 'The Role of Different Channels in Transmitting Monetary Policy into Output and Price in Vietnam', 17(1), pp. 20-40 